\title{
REVIEW
}

\section{Galls and tumor-like growths on marine macroalgae}

\author{
Kirk E. Apt \\ Department of Biological Sciences, University of California, Santa Barbara, California 93106, USA
}

\begin{abstract}
Galls and tumor-like growths can be found on numerous marine macroalgae. These growths are characterized by cell hyperplasia and hypertrophy producing an abnormal unorganized cell proliferation. Host tissues involved are typically differentiated and are induced to become meristematic after infection. These growths are associated with bacteria, algae, fungi, various animals, and other agents.
\end{abstract}

\section{INTRODUCTION}

Most of us are familiar with hyperplasia (galls) on terrestrial plants. Mani (1964), in his extensive treatise on plant galls, defined them as pathologically developed cells, tissues or organs of plants that have arisen mostly by hypertrophy (cell enlargement) and hyperplasia (cell proliferation) under the influence of parasitic organisms such as bacteria, fungi, and various animals (e.g. nematodes and insects). Additional information regarding the development and morphology of terrestrial plant galls can be found by consulting Mani (1964) and Meyer \& Maresquelle (1983).

A number of analogous growths occur on marine macroalgae. These growths are associated with bacteria, fungi, other algae, nematodes, copepods, industrial pollutants, and unknown causes. Earlier literature was previously summarized by Trotter (1901), Merola (1956) and Tokida (1958). A general review on marine algal pathology can be found in Andrews (1976). Morphologically these growths are characterized by host cell hyperplasia and hypertrophy producing an abnormal callus-like unorganized cell proliferation. Typically, the host cells involved are initially differentiated and non-meristematic, but are induced to redifferentiate and become meristematic following infection. Cell growth and cell division are not coordinated as in normal development. As a result, the general develop- ment of the gall growths is a pronounced departure from the general morphogenetic restraints of the thallus.

Each of the major types of association will be summarized individually.

\section{BACTERIA}

As with the terrestrial flora (Riker et al. 1946) numerous seaweeds are apparently induced by bacteria to form galls (see Table 1). However, the nature of the interaction is poorly understood.

Work by Cantacuzene (1930) concerning the development of galls on species of the red algae Chondrus, Cystoclonium and the brown alga Fucus is one of the earlier and more thorough investigations. He described outgrowths which appeared on the base, stipe and lamina of infected thalli; these varied in size depending on their age and location. The largest growths appeared on the older portions of the host. Typically the growths were highly contorted in appearance with older portions of the gall senescing. Cantacuzene (1930) stated that primary tumors 'metasize', producing secondary growths in a linear pattern. Intervening tissues were hyperplastic and may or may not contain bacteria. Unlike crown gall of higher plants, bacteria were present in the secondary tumours and there is no evidence to date for a tumor-inducing 
Table 1. Galls and tumorous growths reported on marine macroalgae

\begin{tabular}{|c|c|c|}
\hline Algal species and inducing agent & Presumed cause & Source \\
\hline \multicolumn{3}{|l|}{ Bacteria } \\
\hline Ahnfeltia plicata & Not isolated & Chemin 1937 \\
\hline Bonnemaisonia asparagoides & Not isolated & Chemin 1937 \\
\hline Ceramium rubrum & Not isolated & Chemin 1932 \\
\hline Chantransia spp. (= Acrochaetum spp.) & Not isolated & Brand 1897, Starmarch 1930 \\
\hline Chondrus crispus & Not isolated & Schmitz, 1892, Cantacuzene 1930 \\
\hline Curdiea laciniata & Not isolated & Schmitz 1892 \\
\hline Cystoclonium purpureum & Not isolated & Schmitz 1892, Chemin 1937 \\
\hline Delesseria sanguinea & Not isolated & Schmitz 1892 \\
\hline Dumontia filiformis & Not isolated & Schmitz 1892 \\
\hline Fucus lutarius ( $=F$. vesiculosus) & Not isolated & Lami 1946 \\
\hline Fucus platycarpus ( $=F$. spiralis) & Not isolated & Lami 1946 \\
\hline Gigartina teedii & Not isolated & Schmitz 1892, Tsekos 1982 \\
\hline Grateloupia filicina & Not isolated & Schnniz 1692 \\
\hline Rhodymenia palmata (= Palmaria palmata) & Not isolated & Schmitz 1892 \\
\hline Plocamium coccineum $(=P$. cartilagineum $)$ & Not isolated & Chemin 1937 \\
\hline Polyneuropsis stolonifera & Not isolated & McBride et al. 1974 \\
\hline Prionitis decipiens & Not isolated & Schmitz 1892 \\
\hline Prionitis lanceolata & Not isolated & Schmitz 1892, McBride et al. 1974, Apt 1985 \\
\hline Pterocladia capillacea & Not isolated & Felicini \& Perrone 1972 \\
\hline Saccorhiza bulbosa & Isolated (?) & Cantacuzene 1928a, 1928b, 1930 \\
\hline Schizymenia dubyi & Not isolated & Lami 1946 \\
\hline \multicolumn{3}{|l|}{ Fungi } \\
\hline Cystoseira balearica & Haloguignardia & Kohlmeyer \& Demoulin 1981 \\
\hline Cystoseira osmundacea & Haloguignardia & Estee 1913, Kohlmeyer \& Kohlmeyer 1979, Apt $1988 \mathrm{~b}$ \\
\hline Cystophora retroflexa & Massarina & Kohlmeyer \& Kohlmeyer 1979 \\
\hline Cystophora subfarcinata & Massarina & Kohlmeyer \& Kohlmeyer 1979 \\
\hline Halidrys dioica & Haloguignardia & Estee 1913, Kohlmeyer \& Kohlmeyer 1979 \\
\hline Sargassum daemelii & Haloguignardia & Cribb \& Cribb 1956, Kohlmeyer \& Kohlmeyer 1979 \\
\hline S. decipiens & Haloguignardia & Cribb \& Cribb 1956, Kohlmeyer \& Kohlmeyer 1979 \\
\hline S. fallax & Haloguignardia & Cribb \& Cribb 1956, Kohlmeyer \& Kohlmeyer 1979 \\
\hline S. fluitans & Haloguignardia & Kohlmeyer \& Kohlmeyer 1979 \\
\hline S. globulariaefolium & Haloguignardia & Cribb \& Cribb 1956, Kohlmeyer \& Kohlmeyer 1979 \\
\hline S. natans & Haloguignardia & Kohlmeyer \& Kohlmeyer 1979 \\
\hline S. sinclairii & Haloguignardia & $\begin{array}{l}\text { Cribb \& Cribb 1956, Kohlmeyer \& Kohlmeyer } 1979, \\
\text { Kohlmeyer \& Demoulin } 1981\end{array}$ \\
\hline S. undulatum & Haloguignardia & Kohlmeyer \& Demoulin 1981 \\
\hline \multicolumn{3}{|l|}{ Algae } \\
\hline Cystoseira ericoides & Herponema & Sauvageau 1892 \\
\hline Cystoseira opuntioides & Streblonemaopsis & Valiante 1883, Feldmann 1937 \\
\hline Laminaria flexicaulis $(=L$. digitata $)$ & Ectocarpus & Dangeard 1931 \\
\hline Laminaria japonica & Streblonema & Apt $1988 \bar{a}$ \\
\hline Laminaria saccharina & Streblonema & Andrews 1977 , Apt 1988 a \\
\hline Macrocystis integrifolia & Streblonema & Andrews 1977, Apt 1988 a \\
\hline Nereocystis luetkeana & Streblonema & Andrews 1977, Apt 1988a \\
\hline \multicolumn{3}{|l|}{ Animals } \\
\hline Ascophyllum nodosum & Nematode & Barton 1892, deMan 1892 \\
\hline Chondrus crispus & Nematode & deMan 1892, Barton 1901 \\
\hline Desmarestia aculeata & Nematode & Barton 1892, deMan 1892 \\
\hline Fucus vesiculosus & Nematode & Coles 1958 \\
\hline Furcellaria fastigiata (= F. lumbricalis) & Nematode & deMan 1892, Barton 1901 \\
\hline Rhodymenia palmata (= Palmaria palmata) & Copepod & Barton 1891, Brady 1894, Harding 1954 \\
\hline Vaucheria spp. & Rodifer & Trotter 1901, Merola 1956 \\
\hline \multicolumn{3}{|l|}{ Other } \\
\hline Ceramium spp. & Unknown & Dixon 1960 \\
\hline Fucus serratus & Unknown & Brucker 1958, Künzenbach \& Brucker 1960 \\
\hline Gracilaria confervoides & Unknown & Nerola 1952, Chemin 1937 \\
\hline Gracilaria epihippisora & Unknown & Apt 1984 \\
\hline Gracilaria verrucosa & Unknown & Tripodi \& Beth 1976 \\
\hline Porphyra tenera & Pollution & Ishio et al. $1971,1972 a, b, c$, Watanabe \& Kato 1972 \\
\hline
\end{tabular}


principle'. (For a review of higher plant tumor systems see Gelvin 1984.)

The galls as described by Cantancuzene (1930) were proliferations of inner (medullary) tissue containing bacteria in the intercellular spaces. The bacteria were isolated and partially characterized but they were not classified, nor were there indications as to the purity of the isolates. Galls were induced by inoculating healthy algae with the isolated bacterial cultures or homogenized galls. Apparently similar organisms were present in each of the host species studied and Cantacuzene (1930) concluded that they were the pathogenic agent, based on their strict association with gall growths, the damaging action they caused on the host, their affinity for specific tissues and their induction of galls on thalli inoculated artificially.

McBride et al. (1974) studied the cytology of red algal galls and concluded that Lobocolax deformans Howe, originally described as a distinct parasitic red algal species, was a proliferation of host tissue of Prionitis lanceolata induced by bacterial infection. The appearance and structure of the tumors were much the same as those described by Cantacuzene (1930). Affected cells were smaller and less regular than adjacent medullary cells. At the ultrastructural level, small proplastids containing few thylakoids replaced the welldeveloped plastids, and nucleic acid areas of the chloroplasts were more conspicuous. Cell wall structure and certain cytoplasmic membrane systems were also altered. The bacteria were rods of $1 \times 2 \mu \mathrm{m}$ and appeared as typical prokaryotes. Tsekos (1982) examined bacteria-associated galls on Gigartina teedil and found results similar to those of McBride et al. (1974).

Recent infection studies (Apt 1985) on bacteriaassociated growths on Prionitis lanceolata (Fig. 1) have shown that gall growths can be induced on healthy uninfected hosts by application of homogenized gall tissue. Development of hyperplasia only occurs if the causative agent comes into contact with internal medullary cells through a wound site. These internal cells begin unorganized cell divisions forming a calluslike cell mass which displaces and disrupts the surrounding normal cells. The adjacent cortical cells do not participate in gall formation. The causative agent has been found to be of bacterial size, but the specific bacterium responsible for these growths has not been identified

\section{ALGAE}

Several examples of galls produced by algae (see Table 1) on species of brown algae are known. Sauvageau (1892) described a gall on Cystoseira ericoides caused by the brown alga Herponema valiantei. Valiante (1883) reported Streblonemopsis irritans as causing nodular galls on Cystoseira opuntioides. Ectocarpus deformans was considered the cause of gall growths on Laminaria digitata (Dangeard 1931).

Galls found on the stipes of Nereocystis, Laminaria and Macrocystis (Fig, 2) were invariably associated with a filamentous and endophytic Streblonema-like brown alga (Andrews 1977). These growths were quite large compared to the thickness of stipes bearing them. In general, they appeared as round wart-like tumours or as highly convoluted elongated ridges (up to $20 \mathrm{~cm}$ long)

Filaments of Streblonema sp. have been isolated from hyperplasia on Nereocystis luetkeana and characterized in culture (Apt 1988a). When inoculated on juvenile thalli of the brown algal kelps Laminaria japonica, Nereocystis luetkeana and Macrocystis integrifolia, filaments of Streblonema sp. induced identical growths to those found in nature. Hyperplasia originates from the internal cells of the epidermal meristematic zone. These cells are induced to divide in a highly irregular and unorganized manner, producing a structure that is a distinct departure from normal morphogenesis. These growths are unusual because the organism which causes cell proliferations belongs taxonomically to the same phylum as the host.

\section{FUNGI}

Fungal infections associated with galls are caused by species of Haloguignardia and Massarina, which infect a number of phaeophycean species (see Table 1). These galls (Fig. 3) take the form of subglobose, ellipsoidal or elongated outgrowths which are more or less prominent protuberances containing ascocarps and spermogonia. Algal genera attacked by Haloguignardia spp. are Cytoseira, Halidrys and Sargassum. Massarina cystophorae forms galls on the genus Cystophora.

The tissue of Cystoseira osmundacea undergoes pronounced developmental changes (Apt 1988b) when in association with the fungus Haloguignardia irritans. Non-meristematic differentiated cortical cells are induced to dedifferentiate and begin dividing in a random manner forming a callus-like tissue. As the infection continues this tissue is induced to redifferentiate into a structure composed of tightly packed clubshaped projections. This structure is unique to the association and has no counterpart in normal morphology. Each projection contains a single fungal reproductive conceptacle (ascocarp or spermogonium). Algal host tissue completely surrounds the fungal reproductive structures and appears to function as a protective layer replacing the need for a thick ascocarp or sper- 

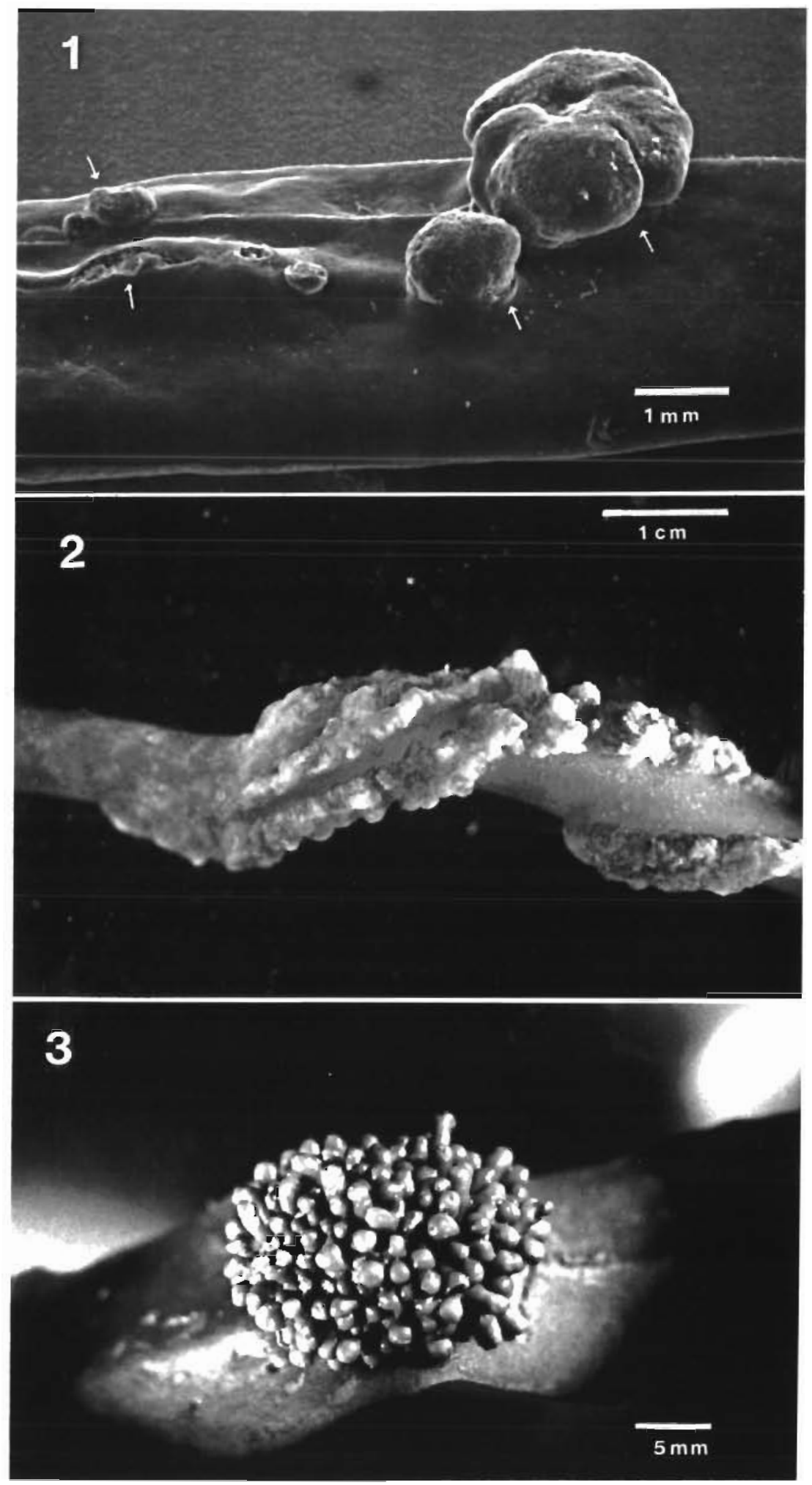

Figs. 1 to 3. Galls on marine macroalgae Fig. 1. Scanning electron micrograph of Prionitis lanceolata with bacteria-associated galls (arrows). Gall tissue has split the cortical tissue and emerged from the intemal medullary region. Infection was conducted in the laboratory. Fig. 2. Stipe of Nereocystis luetkeana infected with Steblonema. Convoluted gall tissue spirals down the stipe. Non-infected tissue retains smooth surface. Fig. 3. Frond of Cystoseira osmundacea with Haloguignardia-assoclated gall. Gall is composed of numerous tightly packed club-shaped projections 
mogonial wall. The association of fungus with $C$. osmundacea is not a simple matter of the fungus developing inside the alga: algal morphology is significantly altered in the association to the apparent advantage of the fungus.

\section{ANIMALS}

Relatively little is known about gall-inducing animals on seaweeds (see Table 1). Nematodes described by Barton (1892) were associated with small, round galls on the brown algae Ascophyllum and Desmarestia. DeMan (1892), who examined Barton's specimens, described the nematode which is now known as Halenchus fucicola. Coles (1958) reported this species and Halenchus dumnonicus found in galls on the brown alga Fucus vesiculosus. Barton $(1891,1901)$ discovered nematodes in galls on the red algae Palmaria, Furcellaria, and Chondrus. However, a copepod was apparently responsible for the symptoms on Palmaria and whether nematodes were the causal agents in the latter 2 cases was not established. It is also not clear from the descriptions provided by the above-mentioned authors just how much, if any, cell proliferation had taken place or if any internal structural modifications were evident.

\section{CARCINOGENIC COMPOUNDS}

There is little information about the effects of carcinogenic compounds on marine algae and most of what is known has been derived from short-term experiments. Certain polycyclic aromatic hydrocarbons stimulate abnormal growth and may be oncogenic. At low concentrations these compounds induced increased cell growth in red algal sporelings (Boney \& Corner 1962, Boney 1974). Tumor-like structures developed on fronds of the red alga Porphyra tenera when these were placed in contact with mud from polluted waters that was subsequently shown to contain 2-chloranthraquinone and reduced dibenzanthrone (Ishio et al. 1971, 1972a, b, c, Watanabe \& Kato 1972). Similar growths appeared on $P$. tenera exposed in the laboratory for several weeks to these purified compounds at concentrations of less than $1 \mathrm{ppm}$. It is not known how if at all these cells differ biochemically or genetically from their untreated counterparts.

\section{OTHERS}

There are no confirmed reports of tumor-like growths caused by viral or genetic abnormalities on marine algae. One possible viral case is the growths found on the red alga Gracilaria epihippisora by Apt (1984). They were not associated with exogenous microorganisms, but were associated with virus-like particles (VLP) present within the cytoplasm (Apt unpubl.). However, these VLP's have not been shown to be the cause of the abnormal growths. These growths are derived from epidermal meristematic cells which have apparently lost their ability to differentiate, and divide randomly producing a callus-like mass. This cell mass, when excised, continues to proliferate as an undifferentiated tissue mass. Along with morphology these growths have a distinct cell wall composition and ultrastructure.

Tripodi \& Beth (1976) described 'caterpillar-like' bodies within abnormal growths on the red alga Gracilaria verrucosa. These unusual bodies were found only within the cells of the swellings and were absent from cells of normal tissue. It is not clear what relationship, if any, these bodies have with inducing abnormal growths.

Künzenbach \& Brucker (1960) attempted to infect 44 different marine green, brown and red algae with the bacterium Agrobacterium tumefaciens, which causes tumors on higher plants. No detectable changes in differentiation or morphology were observed.

\section{CONCLUSIONS}

Observations on algal galls have been made for ca $100 \mathrm{yr}$. The majority of these reports have dealt with the gross morphology. The growths are apparently common on a variety of algae (Dixon 1973), but are rarely reported or examined in detail. In only one case has the infecting organism been isolated, identified and demonstrated to be the causative agent. There is no information available on the biochemical or genetic interactions between pathogen and host.

One significant similarity between the different gall types is that, in every case examined in detail, cell proliferations originate from specific areas. The bacteria-associated galls on Prionitis originate only from internal medullary tissue; other tissues are not affected. Another similarity is that the growths are typically composed of a single cell type, forming a homogeneous unorganized tissue. Notable exceptions are the growths associated with the fungus Haloguignardia. These growths are composed of several specific tissues.

The study of higher plant systems has shown that pathogenic microorganisms and the growth regulatory substances they produce play an important role in gall formation. It is likely that microorganisms associated with algal galls and the substances they produce are also important in the induction of cell division in gall formation on marine macroalgae. The nature of the 
interaction between gall inducer and host should provide valuable information on general development and processes coordinating cell growth and division in marine algae.

\section{LITERATURE CITED}

Andrews, J. H. (1976). The pathology of marine algae. Biol Rev. 51: 211-253

Andrews, J. H. (1977). Observations on the pathology of seaweeds in the Pacific Northwest. Can. J. Bot. 55: 1019-1027

Apt, K. E. (1984). Tumour-like growths on Gracilaria epihippisora Hoyle. J. Phycol. 24 (Suppl.): 24

Apt, K. E. (1985). Studies on neoplastic growths on marine algae. J. Phycol. 25 (Suppl.): 4

Apt, K. E. (19988a). Deveiopment and etiology of hyperpiasid induced by Streblonema (Phaeophyta) on members of the Laminariales (Phaeophyta). J. Phycol. 24: 28-34

Apt. K. E. (1988b). Morphology and development of hyperplasia on Cytoseira osmundacea (Phaeophyta) associated with Haloguignardia irritans (Ascomycotina). Am. J. Bot. 75: 979-984

Barton, E. S. (1891). On the occurrence of galls in Rhodymenia palmata Grev. J. Bot. 29: 65-68

Barton, E. S. (1892). On malformations of Ascophyllum and Desmarestia. Phycological Memoirs, London, Part 1: 21-24

Barton, E. S. (1901). On certain galls in Furcellaria and Chondrus. J. Bot. 39: 49-51

Boney, A. D. (1974). Aromatic hydrocarbons and the growth of marine algae. Mar. Pollut. Bull. 5: 185-186

Boney, A. D., Corner, E. D. S. (1962). On the effects of some carcinogenic hydrocarbons on the growth of sporelings of marine algae. J. mar. biol. Ass. U.K. 42: 579-585

Brand, F. (1897). Uber Chantransia und die einschlägigen Formen der bayerischen Hochebene. Hedwigia 36: 300-319

Brady, G. S. (1894). On Fucitrogus rhodymeniae, a gall-producing copepod. J. R. microsc. Soc. 1984: 168-170

Brucker, W. (1958). Zur Bildung von Tumoren an Meeresalgen. I. Arch. Geschwulstforschg 14: 10-11

Cantacuzene, A. (1928a). Structure anatomique des tumeurs bactériennes de Saccorhiza bulbosa. C. r. Séanc. Soc. Biol. 99: $1715-1717$

Cantacuzene, A. (1928b). Tumeurs bactériennes des thalles de Saccorhiza bulbosa. C. r. Séanc. Soc. Biol. 99: 565-566

Cantacuzene, A. (1930). Contribution à l'étude des tumeurs bactériennes chez les Algues marines. Thèse présentée à la Faculté des Sciences de l'Université de Paris

Chemin, E. (1932). Sur l'existence de galles chez Ceramium rubrum. C. r. Séanc. Soc. Biol. 109: 135-151

Chemin, E. (1937). Rôle des bactéries dans la formation des galles chez les Floridales. Ann. Sci. Nat. Bot. 19: 61-71

Coles, J. W. (1958). Nematodes parasitic on seaweeds of the genera Ascophyllum and Fucus. J. mar. biol. Ass. U.K. 37 $145-155$

Cribb, A. B., Cribb, J. W (1956). Marine fungi from Queensland. II. Univ. Queensl. Pap., Dept Bot. 3: 97-105

Dangeard, P. (1931). Sur un Ectocarpus parasite provoquant des tumeurs chez le Laminaria flexicaulis (Ectocarpus deformans nov. sp.). C. r. hébd. Soc. Biol. 192: 57-60

deMan, J. G. (1892). Über eine neue in Gallen einer Meeresalge lebende Art der Gattung Tylenchus Bast. Festschrift zum Siebenzigsten Geburtstage Rudolf Leuckart 16: $121-125$
Dixon, P. S. (1960). Studies on marine algae of the British Isles. The genus Ceramium. J. mar. biol. Ass. U.K. 39: 315-374

Dixon, P. S. (1973). Biology of the Rhodophyta. Oliver \& Boyd, Edinburgh

Estee, L. M. (1913). Fungus galls on Cystoseira and Halidrys. Univ. Calif., Berkeley, Publ. Bot. 4: 305-316

Feldmann, J. (1937). Les algues marines de la côte des Albères, I-III. Rev. Algol, 9: 184

Felicini, G. P., Perrone, C. (1972). Sulla formazione di galle nella rigenerazione di Pterocladia capillacea (Gmel.) Born. et Thur. in coltura. Giorn. Bot. Ital. 106: 351-358

Gelvin, S. B. (1984). Plant Tumorigenesis. In: Kosuge, T., Nester, E. (eds.) Plant-microbe interactions, Vol. I. Macmillian, New York, p. 343-377

Harding, J. P. (1954). The copepod Thalestris rhodymeniae (Brady) and its nauplius, parasitic in the seaweed Rhodymenia palmata (L.) Grev. Proc. zool. Soc. Lond. 124: 153-161

ishilu, S., Yanu, I., Ñakagana, R. (1971). Algai cancer and causal substances in wastes from the coal chemical industry. In: Proceedings of the 5th International Water Pollution Research Conference, San Francisco and Honolulu 2: $181-188$

Ishio, S., Kawabe, K., Tomiyama, T (1972a). Algal cancer and its causes. I. Carcinogenic potencies of water and suspended solids discharged to the River Ohmuta. Bull. Jap. Soc. Sci. Fish. 38: 17-24

Ishio, S., Nakagawa, H., Tomiyama, T (1972b). Algal cancer and its causes. II. Separation of carcinogenic compounds from sea bottom mud polluted by waters from the coal chemical industry. Bull. Jap. Soc. Sci. Fish. 38: 571-576

Ishio, S., Yano, T., Nakagawa, H. (1972c). Cancerous disease of Porphyra tenera and its causes. In: Proceedings of the 7 th International Seaweed Symposium 7: 373-376

Kohlmeyer, J., Demoulin, V (1981). Parasitic and symbiotic fungi on marine algae. Botanica mar. 24: 9-18

Kohlmeyer, J., Kohlmeyer, E. (1979). Marine mycology. The higher fungi. Academic Press, New York, p. 690

Künzenbach, R., Brucker, W. (1960). Zur Bildung von 'Tumoren' an Meeresalgen. II. Ber. dt. bot. Ges. 73: 8-18

Lami, R. (1946). Notules d'algologie marine X. Quelques galles bactériennes d'algues marines. Bull. Lab. Marit. Dinard. 27: 26-30

Mani, M. S. (1964). Ecology of plant galls. Junk Publ., The Hague

McBride, D. L., Krugens, P., West, J. A. (1974). Light and electron microscopic observations on red algal galls. Protoplasma 79: 249-264

Merola, A. (1952). La cecidologia della Gracilaria confervoides (L.) Grev. del golfo di Napoli. Pubbl. Staz. zool. Napoli 23: $229+$

Merola, A. (1956). Le galle nelle alghe. I. Storia della cecidogenesi nelle alghe. Annali di Botanica (Roma) 25. $1-21$

Meyer, J., Maresquelle, H. J. (1983). Anatomie des galles Encyclopedia of Plant Anatomy. Vol. XIIl pt. I. Gebrüder Bornträger, Berlin

Riker, A. J., Spoerl, E., Guts, A. E. (1946). Some comparisons of bacterial plant galls and their causal agents. Bot. Rev. 12: $57-82$

Sauvageau, C. (1892). Sur quelques algues phéosporées parasites. J. Bot. 6: 57

Schmitz, F. (1892). Über knöllchenartige Auswüchse an den Sprossen einiger Florideen. Bot. Ztg 50:624

Starmarch, K. (1930). Die Bacteriengallen auf manchen SüBwasserarten der Gattung Chantransia. Acta Soc. Bot. Poloniae $7 \cdot 435-460$ 
Tokida, J. (1958). A review of galls in seaweeds. Bull. Jap. Soc. Phycol. 6: 93-99

Tripodi, G., Beth, K. (1976). Unusual cell structures in tumorlike formations of Gracilaria (Rhodophyta). Arch. Microbiol. 108: 167-174

Trotter, A. (1901). Studi cecidologici I. La cecidogenesi nelle alghe. Nouva Notarista 12: 7-24

Tsekos, I. (1982). Tumour-like growths induced by bacteria in the thallus of a red alga, Gigartina teedii (Roth) Lamour. Ann. Bot. 49: 123-126

Valiante, R. (1883). Sopra un Ectocarpia parassita del Cystoseira opuntioides-Streblonemopsis irritans. Boll. zool Sta. Naples, 6: 489

Watcnabe, T., Kato, S. (1972). Studies on the diseases of cultural Porphyra-IV. On the cause of cancer disease. Bull. Jap. Soc. scient. Fish. 38: 431-437

Responsible Subject Editor Professor S. Bonotto; accepted for printing on April 12, 1988 